\title{
Correction to: Study on the safety and effectiveness of drug-coated balloons in patients with acute myocardial infarction
}

Xiaojiao Hao, Damin Huang, Zhaoxia Wang, Jinchun Zhang, Hongqiang Liu and Yingmin Lu*

\section{Correction to: Journal of Cardiothoracic Surgery (2021) 16:178 https://doi.org/10.1186/s13019-021-01525-8}

The original article [1] contained errors in the manifestation of the authorship which have since been corrected.

Published online: 03 September 2021

\section{Reference}

1. Hao X-J, et al. Study on the safety and effectiveness of drug-coated balloons in patients with acute myocardial infarction. J Cardiothorac Surg. 2021;16:178. https://doi.org/10.1186/s13019-021-01525-8.

\section{Publisher's Note}

Springer Nature remains neutral with regard to jurisdictional claims in published maps and institutional affiliations.

The original article can be found online at https://doi.org/10.1186/s13019021-01525-8.

*Correspondence: luym2021cn@163.com

Department of Cardiology, Xinhua (Chongming) Hospital, School

of Medicine, Shanghai Jiaotong University, Shanghai 200000, China original author(s) and the source, provide a link to the Creative Commons licence, and indicate if changes were made. The images or other third party material in this article are included in the article's Creative Commons licence, unless indicated otherwise in a credit line to the material. If material is not included in the article's Creative Commons licence and your intended use is not permitted by statutory regulation or exceeds the permitted use, you will need to obtain permission directly from the copyright holder. To view a copy of this licence, visit http://creativecommons.org/licenses/by/4.0/. The Creative Commons Public Domain Dedication waiver (http://creativeco mmons.org/publicdomain/zero/1.0/) applies to the data made available in this article, unless otherwise stated in a credit line to the data. 